\title{
Strengthening Laboratory Functions in Improving the Quality of Islamic Education Management Study Program IAIN Curup
}

\author{
Muhammad Amin \\ Institut Agama Islam Negeri (IAIN) Curup \\ dg.m.amin@gmail.com \\ Rambat Nur Sasongko \\ Universitas Bengkulu \\ rambatnursasongko@unib.ac.id \\ Manap Somantri \\ Universitas Bengkulu \\ manap@unib.ac.id \\ Nirwana \\ Universitas Bengkulu \\ ananirwana.adlan@gmail.com \\ Arsil \\ Institut Agama Islam Negeri (IAIN) Curup \\ arsiluj@gmail.com \\ Karliana Indrawari \\ Institut Agama Islam Negeri (IAIN) Curup \\ karlianaindrawari@gmail.com
}

\begin{abstract}
The study program has many practical courses and wants to graduate to have real skills. The IAIN Curup Islamic Education Management study program directs its graduates to become educational staff at Islamic education institutions and agencies that handle education, become institutional managers, become Islamic education management researchers, and become planners and developers of ICTbased learning resources. So the existence or availability of a laboratory is a must. The research objectives were to determine the needs of lecturers and students of the IAIN Curup Islamic Education Management Study Program for laboratories and to determine the strengthening of laboratories in improving the quality of the IAIN Curup Islamic Education Management Study Program. This type of field research (Field Research) with qualitative research methods. Sources of data from the Head of Study Program, lecturers, laboratory managers and students of the MPI IAIN Curup study program, observation data collection techniques, interviews and documentation. Researchers analyzed the data with the stages of reducing data, presenting data, and drawing conclusions. The results of the research are the need for lecturers and students of the IAIN Curup Islamic Education Management Study Program to strengthen the function of labor because there is a mandatory leadership practice course for Islamic Education Management students, and students are required to have various abilities, both work skills, knowledge, and the ability to become leaders. Strengthening the labor function of the IAIN Curup Islamic Education Management Study Program is carried out in a number of stages, namely (1) creating a labor organization structure consisting of the Chair of the
\end{abstract}


Labor, secretary, laboratory assistant, technicians and students, (2) making laboratory administration, (3) preparing laboratory facilities and infrastructure. study program, (3) create a labor curriculum. And (4) study program labor is designed with a U-shape model.

Keywords: Strengthening, Laboratory, Quality

\begin{abstract}
Abstrak: Program studi memiliki banyak mata kuliah praktek dan menginginkan lulusnya mempunyai skill secara nyata. Program studi Manajemen Pendidikan Islam IAIN Curup mengarabkan lulusannya menjadi tenaga kependidikan pada lembaga pendidikan Islam dan instansi yang menangani pendidikan, menjadi pengelola lembaga, menjadi peneliti manajemen Pendidikan Islam, dan menjadi perencana serta pengembang sumber belajar berbasis ICT. Maka keberadaan atau tersedianya Laboratorium menjadi sebuah keharusan. Tujuan penelitian untuk. mengetahui kebutuhan dosen dan mahasiswa Program Studi Manajemen Pendidikan Islam IAIN Curup akan laboratorium dan untuk mengetahui Penguatan labororatorium dalam meningkatkan mutu Program Studi Manajemen Pendidikan Islam LAIN Curup. Jenis penelitian lapangan (Field Research) dengan metode penelitian kualitatif. Sumber data dari Ketua Prodi, dosen, pengelola lab dan mahasiswa prodi MPI LAIN Curup, Tekhnik pengumpulan data observasi, Interviu dan dokumentasi. Peneliti menganalisis data dengan tabapan mereduksi data, penyajian data, dan penarikan kesimpulan. Hasil penelitian adalab Kebutuban dosen dan mahasiswa Program Studi Manajemen Pendidikan Islam IAIN Curup akan penguatan fungsi labor karena adanya mata kuliah praktek kepemimpinan bersifat wajib bagi mahasiswa Manajemen Pendidikan Islam, serta mahasiswa dituntut memiliki berbagai kemampuan baik. skill kerja, knowledge, dan kemampuan menjadi pemimpin. Penguatan fungsi labor Program Studi Manajemen Pendidikan Islam LAIN Curup dilakukan dengan berapa tahapan yaitu (1) membuat struktur organisasi labor terdiri dari Ketua Labor, sekretaris, laboran, teknisi dan mahasiswa, (2) membuat administrasi laboratorium, (3) menyiapkan sarana dan prasarana labor program studi, (3) membuat kurikulum labor. Serta (4) labor program studi didesain dengan model U-shape.
\end{abstract}

Kata Kunci: Penguatan, Laboratorium, Mutu

\title{
INTRODUCTION
}

Learning is essentially a process of interaction between students and the surrounding environment so that changes in behavior occur for the better (Hosnan, 2014). Learning activities as an effort to grow and develop all the potential of students both in terms of knowledge, attitudes and skills. One method of growing and developing all student potential is to provide a laboratory. Laboratories are needed as a means of increasing students' knowledge and skills in practical courses.

Based on the results of Utari's research, the laboratory should accelerate the distribution of knowledge to the public through programmed scientific activities. The implementation of laboratory activities needs to be supported not only by facilities but also administration, documentation and publications. And optimization of the department's laboratory must be supported by adequate university policies and the expansion of partners by the department. 
The laboratory is one of the practicum learning infrastructure that can be used as a place to train students in understanding concepts, theories and improving skills in practical courses as stipulated in the Minister of Education and Culture Regulation No. 49 of 2014 which states explicitly in article 31 that the laboratory is one of the standards of learning infrastructure. (Utari, 2017)

In the world of education, especially for study programs that have more practical courses and want graduates to have real skills or abilities. The Islamic Education Management Study Program IAIN Curup directs its graduates to become educational staff at Islamic educational institutions and agencies that handle education; become managers of educational institutions (Madrasah, Schools, Islamic Boarding Schools, Majlis Taklim, Diniyah Takmiliyah, Course Institutions, Education and Training Centers, Study Groups, and community activity centers); become a researcher in Islamic Education management; and become a planner and developer of ICT-based learning resources. So the existence or availability of a laboratory is a must. Scientific learning, both scientific processes, scientific products and scientific attitudes requires a laboratory.

The existence of a laboratory as a medium for students to practice learning cannot be separated from practicum courses and practical courses that must be taken by every student. These courses are very unlikely to be carried out perfectly without a laboratory. If there are practical courses and practical courses, it is also required that there must be a laboratory. The laboratory is attached to the practicum. Therefore, a representative laboratory is needed so that students or lecturers have the opportunity to conduct trials, investigate and prove concretely what they have obtained in theories in the classroom or obtained from the literature to be actualized to the public. Hasan, 2014).

In the era of globalization, it is necessary to redesign the curriculum that is guided by the IQF curriculum, so that higher education both abroad and within the country has the same quality. Curriculum redesign wants a change in the abilities of students in the form of personality, work skills, knowledge, leadership, and having a sense of responsibility. With this desire and achievement target, universities or colleges must be able to conceptualize courses that are in accordance with the needs of the graduate profile and the needs of the community, so as to produce and form quality graduates.

Presidential Regulation (Perpres) of the Republic of Indonesia Number 8 of 2012 and Regulation of the Minister of Education and Culture of the Republic of Indonesia Number 73 of 2013, requires universities, including the Islamic Education Management Study Program, Faculty of Tarbiyah, IAIN Curup, to simultaneously redesign the curriculum. Implementation in the form 
of the Indonesian National Qualifications Framework (KKNI) curriculum in the field of higher education. Curriculum redesign carried out by study programs must be based on the Indonesian National Qualifications Framework (KKNI) curriculum, with the aim of the education system in higher education clarifying the profile of its graduates, so that it can be adjusted to suitability in terms analysis of community needs.

With the change in the curriculum based on the KKNI curriculum, the Head of the Islamic Education Management Study Program is required to facilitate the Laboratory for courses in the IAIN Curup MPI Study Program. Based on this condition, every educational institution is required to optimize the laboratory. Even the procurement of laboratories in every educational institution is a necessity and a necessity. The purpose of the study was to determine the needs of lecturers and students of the Islamic Education Management Study Program IAIN Curup for laboratories and to determine the strengthening of laboratories in improving the quality of the Islamic Education Management Study Program IAIN Curup.

Rahmania Utari's research in the journal Dinamika Pendidikan Vol. XXII No. 1 May 2017 with the title strengthening and expanding the function of laboratories in the social science cluster in universities. The result of the research is that the laboratory should accelerate the distribution of knowledge to the public through programmed scientific activities. The implementation of laboratory activities needs to be supported not only by facilities but also administration, documentation and publications. And optimization of the department's laboratory must be supported by adequate university policies and the expansion of partners by the department.

Amna Emda's research in the journal Lantadina Vol. 2 No. 2 of 2014 with the title laboratory as a means of learning chemistry in improving knowledge and scientific work skills. The result of the research is that with the existence of the laboratory, students will understand more about the subject by doing scientific works. Therefore students will have a good grip on the scientific work`s step and their knowledge will last longer.

Research by Achmad Anwar Abidin in the journal Quality Assurance Vol. 3 No. 1 of 2017 with the research title Management of Higher Education Financing in Quality Improvement Efforts (Case Study at Private Middle Universities in Surabaya). The result of the research is that management funding education is one of the factors that determine the quality improvement due to the financial management that is transparent and accountable will give rise to the belief of stakeholders and it will be the motivation of each academicians Tri 
Dharma College in private college medium in Surabaya to conduct quality improvements in their respective fields.

\section{RESEARCH METHODS}

This type of research is qualitative research. The main data sources are obtained directly from the Chair of the Study Program, lecturers, laboratory managers and students of the IAIN Curup MPI Study Program and supporting data, namely those obtained from books or literature related to strengthening the laboratory function in improving the quality of the IAIN Curup MPI Study Program.

The data collection technique used in this research is that the first interviews are given to the head of the Study Program and the Head of the Laboratory, lecturers, and students. Both observations were made to record all information obtained and to re-check the truth about strengthening laboratory functions in improving the quality of the IAIN Curup MPI Study Program. Third documentation. Researchers analyzed the data with the stages of reducing data, presenting data, and drawing conclusions (Sugiyono, 2011).

\section{RESULTS AND DISCUSSION}

\section{The need for lecturers and students of the MPI IAIN Study Program is not enough for laboratories}

In order to obtain information about the needs of the head of the study program, the head of the integrated laboratory, lecturers and students, there will be a laboratory for practical courses.

Based on the researcher's interview with the head of the study program, Dr. Irwan Fathurrochman, M.Pd. The Tarbiyah Faculty has an integrated laboratory and micro teaching labor, but the labor is not related to learning in the IAIN Curup MPI study program.. Leadership practice courses are carried out in integrated laboratories and sometimes practice in micro teaching laboratories. The demand for laboratories for lecturers and students will procurement of laboratories in every educational institution is a necessity and a necessity because it makes it easier for lecturers and students to practice leadership theory and other practical courses" andtrain students to become leaders so that students have competencies (knowledge, skills and values in leading).there must be and it is very necessary to strengthen the existing laboratory in the MPI LAIN Curup study program because the existing laboratory is only integrated labor. there is a link between labor and the vision and mission of the MPI Study Program because in the vision and mission of the IAIN Curup MPI Study ProgramThe realization of professional graduates in the field of leadership. A laboratory that can be used by students in practical courses, the existence of an organization in labor, labor administration, laboratory facilities and infrastructure and a special room. 
It can be concluded from the opinion of the head of the MPI IAIN Curup study program that the need for a laboratory is very much needed, because in practical courses students really need a laboratory. And in accordance with the vision and mission of the study program that makes students must be professional in their fields.

The next interview with the head of integrated labor, Dr. Abdul Sahib, M.Pd. there are only integrated labor used by PGMI, Mathematics, PIAUD students. The existing activities in the laboratory are still not optimal. The existing laboratory facilities are still not complete. There should be a laboratory for study programs that have practical courses and even a strengthening of the existing laboratories by providing the facilities needed and creating an organization. Special labor for MPI study program used in leadership practice or microteaching labor"

The conclusion from the opinion of the Head of Integrated Laboratories regarding the need for laboratories at the IAIN Curup MPI Study Program is that the MPI Study Program must provide a special laboratory for the MPI Study Program with the facilitation of adequate facilities and infrastructure.

The next interview with the Lecturer of the MPI Study Program, namely Drs. Syaiful Bahri, M.Pd. The implementation of leadership practice lectures or other practical courses is carried out in the classroom. Really need a laboratory because it's a pity that students only understand theory but not practice. A laboratory that can allow students to practice practical courses. A micro leading laboratory that can make students practice in leadership management courses". "The IAIN Curup MPI study program requires a laboratory where students can practice directly, not just theory.

Likewise, the opinion of the MPI lecturer, namely Mr. Siswanto, M.Pd.I. "In the MPI study program, in practical courses, students use the classroom more. Labor is really needed because theory without practice will make students only know theory but cannot put it into practice. A micro leading laboratory equipped with facilities and infrastructure where students can practice leadership.

The conclusion from interviews with lecturers of the IAIN Curup MPI Study Program regarding the need for laboratories is that students and lecturers really need laboratories in the learning process, especially leadership practice courses.

The next interview with MPI Study Program student, Sella Ponikasari. practical courses are less effective because they do not learn in the laboratory 
but in the classroom. Students really need labor so that we can put the theory we have learned into practice and we can understand it."

Likewise, the opinion of the MPI Study Program student, namely Yuliani. Most practical courses are conducted in the classroom. Students really need so that we can understand how to practice being a leader in the laboratory.

The conclusion from interviews with students of the IAIN Curup MPI study program is that so far students cannot put into practice the theory they get, especially practical courses. A laboratory is needed for students to understand learning, especially leadership management courses or microleading courses.

As research conducted by Irwandi and Zulamri with the title of research on strengthening religious values through social laboratories in flat land. According to Urwandi, the social laboratory is a place to apply science, especially in the field of community empowerment. The presence of the social laboratory is the contribution of universities in the field of developing religious activities.

The design of the Islamic Education Management Study Program at IAIN Curup is based on the principles of needs from lecturers, curriculum, graduate profile needs and the needs of the community and students. Based on the changes in the IQF curriculum, the Head of the Islamic Education Management Study Program is required to facilitate Labor in leadership practice courses. Labor is labor used by students in training to become a leader so that students have competence (knowledge, skills and values in leading).

Students are required to have various abilities, both work skills, knowledge, leadership, and have a sense of responsibility and have a good personality. MPI Study Program graduates will become educational staff at Islamic educational institutions and agencies that handle education; become managers of educational institutions (Madrasah, Schools, Islamic Boarding Schools, Majlis Taklim, Diniyah Takmiliyah, Course Institutions, Education and Training Centers, Study Groups, and community activity centers); become a researcher in Islamic Education management; and become a planner and developer of ICT-based learning resources.

The practical leadership course is mandatory for Islamic Education Management students, which is a continuation of the leadership course which is carried out in a leadership practice format. In the micro leading course, students are asked to practice leadership tasks, such as the practice of leading various models of meetings or meetings, briefings, brainstorming, discussions, seminars 
and workshops in micro leading Labor. So that students are expected to be able to demonstrate the simple tasks of educational leaders.

Every educational institution is required to optimize Labor. Even the procurement of laboratories in every educational institution is a necessity and a necessity.With this desire and achievement target, universities or colleges must be able to conceptualize courses that are in accordance with the needs of the graduate profile and the needs of the community, so as to produce and form quality graduates.

\section{Strengthening laboratories in improving the quality of the Islamic Education Management Study Program IAIN Curup}

The efforts of the IAIN Curup MPI Study Program in improving the quality of graduates so that they have work skills and become educational staff at Islamic educational institutions and agencies that handle education. So it is necessary to strengthen the function of the laboratory.

The ideal laboratory for a study program must have a clear organization, both in terms of structure and personnel. Laboratory organization includes organizational structure, job description and personnel structure that manages the laboratory.

The laboratory manager consists of the head of the laboratory, secretaries, laboratory assistants and technicians. The head of the laboratory is responsible for the planning, maintenance and smooth running of practicum and research activities. The secretary assists the head of the laboratory in managing activities in the laboratory, while laboratory assistants and technicians are responsible for the implementation of activities in the laboratory, namely preparing tools and materials, assisting users in operating the tools and maintaining security and safety during activities.

The MPI Study Program creates a laboratory organizational structure for division of labor, unity of command, and communication channels between leaders and subordinates. The importance of the organizational structure will assist the head of the MPI Study Program in carrying out the laboratory program based on the vision, mission, and objectives of the MPI Study Program.

Physical facilities and infrastructure that support the functioning of the laboratory, in general, should be supported by the following: (1) Availability of adequate space, the laboratory must have a representative room, and be arranged in such a way that it can function properly. Ideally, the perfect layout should start from the planning of the building to the execution of the construction. (2) The existence of complete equipment, this equipment is related to the instruments needed for practicum activities or other scientific activities. The equipment should always be in a ready-to-use condition and always 
available in place or not being moved. The condition is clean, and works well. Each equipment must be accompanied by an operating manual. (3) The existence of laboratory infrastructure, this infrastructure is related to various things, such as; location of laboratories, construction of laboratories and other facilities such as main doors, emergency doors, types of floors, types of cabinets and so on. Then, supporting facilities such as water, electricity, gas, communication tools and work safety support such as fire extinguishers, cameras, and so on. (4) Availability of funding facilities, availability of funds is very much needed in laboratory operations. These funds can be sourced from SPP, routine budgets, from institutions, or it can be from other institutions, as well as donors and so on. The existence of laboratory inventory and security, this means that laboratory inventory and security activities such as procurement of goods and services must be clearly sourced,

In order to support the functioning of the laboratory, the IAIN Curup MPI study program must provide adequate and representative space. Having complete equipment, The existence of laboratory infrastructure, this infrastructure is related to various things, such as; location of laboratories, construction of laboratories and other facilities such as main doors, emergency doors, types of floors, types of cabinets and so on. Then, supporting facilities such as water, electricity, gas, communication tools and work safety support such as fire extinguishers, cameras, and so on. Availability of funding facilities. As well as supporting facilities are needed, namely: (1) 7 units of student long desks, (2) 12 student chairs, (3) 1 unit leadership desk, (4) 2 lead Moveable chair, (5) 1 unit LCD projector, (6) Drop-down screen 1 unit, (7) 1 set of Document camera, (8) 1 set of multimedia computer, (9) 1 unit of printer, (10) 1 unit of AC, (11) 1 unit of white board, (12) 14 units of desk name.

Laboratory Students of the Islamic Education Management Study Program are designed in the form of an adequate room to carry out leadership practices, meetings or meetings. The design is a U-Shape model.

The curriculum is the lifeblood of a learning program that is structured in accordance with the times and the competencies needed by the community and users of university graduates. The laboratory curriculum is a program to produce graduates who master practical courses so that graduates have the equivalent qualifications agreed in the IQF.

The IAIN Curup MPI Study Program makes a Laboratory Curriculum in the form of a leadership practice guide. In the curriculum, students are asked to practice leadership tasks, such as the practice of leading various models of meetings or meetings, briefings, brainstorming, discussions, seminars and workshops in micro leading Labor. So that students are expected to be able to demonstrate the simple tasks of educational leaders. 
Laboratory administration is a recording or inventory of laboratory facilities so that the types and quantities can be known, and can facilitate practical and practical activities.

The IAIN Curup MPI Study Program must have a laboratory administration which includes all administrative activities in the laboratory, including those related to laboratory equipment inventory, a list of new equipment needs or a list of additional tools, a list of damaged tools, borrowed tools or returning tools. Then there is the administration of incoming and outgoing letters, a list of laboratory users according to the practicum schedule, a list of inventory of practice materials and so on. Then no less important, related to the inventory list of tools such as chairs, tables, benches, cabinets and so on.

Research on strengthening the function of social laboratories has been carried out by many previous researchers, such as Utari (2017) who examined the strengthening and expansion of laboratory functions in social science clusters in universities. The research emphasizes the need for universities to change the traditional paradigm of social science laboratories. In addition to strengthening the function of the laboratory, expansion can also be carried out so that the laboratory is not only a teaching or learning laboratory, but also the real of research and community service.

\section{CONCLUSION}

The strengthening of the laboratory function in the Islamic Education Management Study Program IAIN Curup has been started by the head of the MPI study program because of the needs of lecturers and students for laboratories in practical courses and the demands for changes to the KKNI curriculum where students are required to have various abilities, both work skills, knowledge, leadership. The strengthening of the laboratory functions of the Islamic Education Management Study Program IAIN Curup is carried out in several stages, namely (1) Creating a Labor organization structure consisting of the Head of Labor, secretaries, laboratory assistants, technicians and students. (2) Prepare the facilities and infrastructure for the Labor Department of Islamic Education Management at IAIN Curup, namely tables and chairs, LCD projectors, Drop-down screens, Document cameras, Multimedia computers, Printers, White boards, AC, Management desks, and Moveable chairs. (3) Creating a Labor curriculum containing the practice of leading various models of meetings or meetings, briefings, brainstorming, discussions, seminars and workshops in Labor micro leading. So that students are expected to be able to demonstrate the simple tasks of educational leaders. To the leadership of IAIN Curup and all policy makers to further increase their attention in the procurement of laboratory facilities and infrastructure. This research has limitations so that further research needs to be done, namely in the form of 
developing laboratory modules. Hopefully this research can be used as reading material that is useful for all readers and especially writers So that students are expected to be able to demonstrate the simple tasks of educational leaders. To the leadership of IAIN Curup and all policy makers to further increase their attention in the procurement of laboratory facilities and infrastructure. This research has limitations so that further research needs to be done, namely in the form of developing laboratory modules. Hopefully this research can be used as reading material that is useful for all readers and especially writers So that students are expected to be able to demonstrate the simple tasks of educational leaders. To the leadership of IAIN Curup and all policy makers to further increase their attention in the procurement of laboratory facilities and infrastructure. This research has limitations so that further research needs to be done, namely in the form of developing laboratory modules. Hopefully this research can be used as reading material that is useful for all readers and especially writers.

\section{ACKNOWLEDGEMENTS}

The research team would like to thank the BOPTN competitive research committee for providing funding assistance for Litapdimas research in 2020. Thank you to the chair of MPI Study Program, lecturers, head of Labor and students who have helped and provided data and input about our research.

\section{REFERENCE}

A Hasan Basri. (2014). Urgensi Laboratorium BKI Dalam Pengembangan Kompetensi Mahasiswa. Jurnal Hisbah 11 (1).

Anwar, Achmad Abidin. (2017). Manajemen Pembiayaan Pendidikan Tinggi Dalam Upaya Peningkatan Mutu (Studi Kasus Pada Perguruan Tinggi

Swasta Menengah diSurabaya). Jurnal Penjaminan Mutu Pebruari.

Decaprio, Richard. (2013). Tips Mengelola Laboratorium Sekolah. Yogyakarta: Diva Press.

Depdikbud. (1979). Petunjuk Pengelolaan Laboratorium IPA. Bandung: CV. Rosda.

Edward, Sallis. (2012). Total Quality Management In Education: Manajemen Mutu Pendidikan. Yogjakarta: Ircisod.

Eva, E., Yosro, N., Ristianti, D. H., Kusen, K., \& Fathurrochman, I. (2020). Eksistensi Guru Pendidikan Agama Islam dalam Pembentukan Karakter Peduli Lingkungan Peserta Didik. JOEAI: Journal of Education and Instruction, 3(2), 172-178.

Fathurrochman, I., Danim, S., AB, S. A., Kurniah, N., Connie, C., Wachidi, W., \& Ristianti, D. H. (2021, June). Analisis Sistem Pendidikan Negara Federasi Rusia Dalam Meningkatkan Mutu Pendidikan Indonesia. In 
Prosiding Seminar Nasional Program Pascasarjana Universitas PGRI Palembang.

Fitrah, Muh. Ruslan, Hendra. (2018). Urgensi Sistem Penjaminan Mutu Internal terhadap Peningkatan Mutu Perguruan Tinggi, Jurnal Penjaminan Mutu Lembaga Penjaminan Mutu Institut Hindu Dharma Negeri Depansar, 4 (1).

Hartinawati. (2010). Pengelolaan Laboratorium IPA. Jakarta: Unniversitas Terbuka.

Hosnan, M. (2014). Pendekatan Saintifik Dan Konstekstual dalam Pembelajaran Abad 21, Kunci Sukses Implementasi Kurikulum 2013. Jakarta: Ghalia Indonesia.

Irwandi dan Zulamri. (2020). Penguatan Nilai-Nilai Keagamaan Melalui Laboratorium Sosial di Tanah Datar. Jurnal Dakwah Risalah, 31 (1).

Japaruddin, J., Hamengkubuwono, H., Kusen, K., Warlizasusi, J., Yanto, M., \& Fathurrochman, I. (2020). Upaya Kepala Madrasah dalam Meningkatkan

Eksistensi Madrasah Ibtidaiyah Swasta. Alignment: Journal of Administration and Educational Management, 3(2), 87-94.

Lubis, Muhsin. (1997). Materi Pokok Pengelolaan Laboratorium IPA. Jakarta: Depdikbud.

Mastika, Nyoman. (2014). Analisis Standarisasi Laboratorium Biologi dalam Proses Pembelajaran di SMA Negeri Kota Denpasar. E-jurnal program pascasarjana Unniversitas Pendidikan Ganesha, 4.

Mulyono Agus dkk. (2007). Implementasi Sistem Manajemen Mutu UIN Maliki Malang. Malang: LPM UIN Malang.

P. Sitepu. (2014). Pengembangan Sumber Belajar. Jakarta: Raja Grafindo Persada.

Rusman. (2009). Manajemen Kurikulum, Seri Manajemen Sekolah Bermutu. Jakarta: Raja Grafindo Persada.

Sugiyono. (2010). Metode Penelitian Kuantitatif \& kualitatif. Journal of Experimental Psychology: General.

Sugiyono. (2016). Metode Penelitian Kuantitatif, Kualitatif,dan R\&D. CV. Alfabeta.

Sutrisno. (2010). Laboratorium Fisika Sekolah 1. Bandung: Unniversitas Pendidikan Indonesia.

Tilaar, H.A.R. (2012). Standar Pendidikan Nasional, Suatu Tinjauan Kritis. Jakarta: Rineka Cipta.

Utari, L., Kurniawan, K., \& Fathurrochman, I. (2020). Peran Guru Pendidikan Agama Islam dalam Membina Akhlak Peserta Didik Autis. JOEAI: Journal of Education and Instruction, 3(1), 75-89. 
Utari, Rahmania. (2017). Penguatan dan Perluasan Fungsi Laboratorium Pada Rumpun Ilmu Sosial di Perguruan tinggi. Jurnal Dinamika Pendidikan, XXII (1).

Wiyanto. (2008). Menyiapkan Guru Sains Mengembangkan Kompetensi Laboratorium. Semarang: UNNES Press.

Zuhaida, Anggun dan Muhamad Imaduddin. (2019). Analisis Level Literasi Laboratorium Kimia Dari Calon Guru IPA Tahun Pertama. Jurnal Inovasi Pendidikan Kimia, 13 (2). 
136| Tadbir : Jurnal Studi Manajemen Pendidikan, Vol. 5, No. 1, 2021

This page belongs to the Tadbir : Jurnal Studi Manajemen Pendidikan

TADBIR : Jurnal Studi Manajemen Pendidikan Vol. 5, No.1, Mei 2021

IAIN Curup - Bengkulu | p-ISSN 2580-3581; e-ISSN 2580-5037 